\title{
Up in the Air
}

How Airlines Can Improve

Performance by Engaging

Their Employees

Greg J. Bamber

Jody Hoffer Gittell

Thomas A. Kochan

Andrew von Nordenflycht

ILR Press

an imprint of

Cornell University Press

Ithaca \& London 


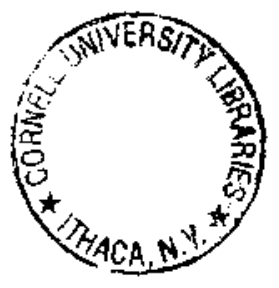

Copyright 2009 by Comell University

All rights reserved. Except for brief quotations in is review, this book, or parts thereof, must not he reproduced in any form without permission in writing from the publisher. For information, address Comell University Press, Sage House, 512 East State Street, Ithaca, New York 14\$50.

First published 2009 by Comell University Press

Printed in the United States of America

\section{Library of Congress Cataloging-in-Publication Data}

Up in the air : how airlines can improve performance by . enguging their employees / Greg J. Bumber . . . [et al.].

p. cm.

Inclucies bibliographical references and index.

ISBN 978-0-8014-4747-1 (cloth : alk. paper)

1. Airlines-United States-Employees. 2. Airlines-United States-Personnel managenent. 3. Airlines-Employees-Labor unions-United States. 4. Industrial relatious-United States. 5. Airlines--Employees. 6. Airlines-Personnel management. 7. Airlines-Employees-Lathor unions. 8. Industrial relations. 1. Bamber, Greg, 1949- II. Title.

HD8039.A42 22 U U583 2009

$397.7065 \%$ ? $\mathrm{dc} 22$

\section{5}

Comell University Press strives to use environmentally responsil)le suppliers and materials to the fullest extent possillie in the publishing of its books. Such materials include vegetable-lyased. low-VOC inks and acid-free papers that are recycled, totally chlorine-ffee, or partly composed of nomwoxd fibers. For fiut her information, visit our website at www.comellpress.comell.edn.

Clothprinting $\quad \begin{array}{lllllllllll}0 & 9 & 8 & 7 & 6 & 5 & 4 & 3 & 2 & 1\end{array}$ 


\section{Property of \\ MARTIN P. CATHERWOOD LIBRARY \\ SCHOOL OF \\ INDUSTRIAL AND LABOR RELATIONS \\ Comell University}

For the late Magdalena Jacobson 


\section{Contents}

Preface ix

1. Low-Cost Competition in the Airline lndustry 1

2. Developments in the U.S. Airline Industry 15

3. Developments in the Airline Industry in Other Countries 28

4. Industry Trends in Costs, Productivity, Quality, and Morale 61

5. Alternative Strategies for New Entrants: Southwest vs. Ryanair $\quad 86$

6. The Legacy Responses: Alternative Approaches 124

7. Building a More Balanced Airline Industry 167

$\begin{array}{ll}\text { Notes } & 199\end{array}$

$\begin{array}{ll}\text { Index } & 215\end{array}$ 


\section{Preface}

We hope that this book will make a contribution to practice as well as to scholarship. The book was made possible by the international research network of the Labor and Employment Relations Association's Airline Industry Council, and in particular by an excellent group of academic colleagues from around the world. We draw on the work of many of them in the book including Michael Barry, Phil Beaumont, Seong-Jae Cho, Geraint Harvey, Laurie Hunter, Byung-Sik Kang, Nancy Brown Johnson, Russell Lansbury, Byoung-Hoon Lee, Robert McKersie, Werner Nienhueser, Sarah Oxenbridge, Judy Pate, Teresa Shuk-Ching Poon, Daphne Taras, Sioblian Tiernan, Peter Turnbull, Joe Wallace, Peter Waring, Lorraine White, Clare Yazbeck, and their colleagues. A series of articles from this network will be published in the International Journal of Human Resource Management in 2009.

We are grateful to the practitioners of the Airline Industry Council who have provided data for and feedback on our work including Phillip Com-

stock, Robert DeLucia, Pat Friend, Jerry Glass, Arthur Luby, Bernhard Rikardsen, Seth Rosen, and Steve Sleigh. We are also grateful to our colleagues in the MIT Global Airline Industry Program including Arnold Barnett, Cynthia Barnhart, Peter Belobaba, John Hansman, James Lee, Amedeo Odoni, Bill Swelbar, and Gerry Tsoukalis who provided data, analysis, insights, and feedback on our ideas. 
Several of those mentioned in this preface made helpful comments on the manuscript, as did Peter Cappelli, Stephen Goldberg, Bruce Highfield, Wayne Horvitz, and Terry O'Connell.

Jacalyn Martelli provided expert help in keeping track of the innumerable drafts of chapters, assembling them into a single text (several times), formatting charts and tables, and coordinating schedules between several countries.

In addition, we thank a range of people who contributed in various ways including Tim Bamber, Colleen Barrett, Jeff Brundage, Mark Burdette, Mike Campbell, Martin Daley, Sharon Ford, Rohan Garnet, Ian Glendon, Al Hemenway, Steve Hill, Julian Howe, Alan Joyce, Thom McDaniel, Ian McLoughlin, Toby Nicol, James Parker, Kate Rainthorpe, Ryan Shields, Steven Sun, Donna Towle, Gerry Turner, Adrian Wilkinson, and Jim Wimberly.

We also thank the various other managers, union officials, academics, and others who have shared their views with us. Please forgive us if we have not mentioned your name. There are too many people to name personally and some spoke with us on an anonymous basis.

Our research was facilitated by funding from several sources including the Alfred P. Sloan Foundation, the Australian Research Council, the MIT Global Airline Industry Program, the Social Science and Humanities Research Council of Canada, and the U.S. Federal Mediation and Conciliation Service.

For permission to reproduce or reinterpret data or illustrations, we acknowledge Rigas Doganis (figure 3.1), Personnel Today ("British Airways: Examples of Adversarial Employment-Relations Episodes" in chapter 3), and the International Civil Aviation Organisation via Flight Global (many of the tables in chapter 4).

We very much appreciate the guidance and professionalism of Cornell University Press, a leading publisher in our field. Those who have helped us include Fran Benson, Mary-Anne Gilbert, John Raymond, Susan Specter, and their colleagues.

Our good friend and colleague Magdalena Jacobson, former chair of the National Mediation Board and past president of the Industrial Relations Research Association, lost her battle with cancer as we were completing this book. Maggie was a source of inspiration. She put to work principles of our profession that we hold dear: a dedication to public service; an integrity that earned the trust and respect of labor, management, and academic professionals; and a determination to make a difference in people's lives that rubbed 
off on anyone lucky enough to work with her. We hope that soon we will see a return of the caliber and style of leadership she brought to the airline industry and to the national administration of U.S. labor and employment policies.

Our greatest debt is to our families, who have given us their generous support, as usual, while we worked on this book.

May 2008 
Up in the Air 


\section{CHAPTER 1}

\section{Low-Cost Competition in the Airline Industry}

These words from a front-page story in the December 22, 2007, issue of the New York Times should serve as a wake-up call to all those responsible for America's air transportation system: "And you thought the passengers were mad. . . A Airline employees are fed up, too-with pay cuts, increased workloads and management's miserly ways, which leave workers to explain to often-enraged passengers why flying has become such a miserable experience." The story goes on to report comments from US Airways' employees in a question-and-answer session with their chief executive officer. The employees' frustrations came through loud and clear about working for the airline with the most passenger complaints and mishandled bags and the lowest rate of on-time arrivals:

"I hate to tell you but the interiors of our planes smell bad and they are filtly. As an employee I am embarrassed to adinit working for US Airways."

"How long do you think the airline will be around the way it's running right now?"

Something is fundamentally wrong when both an industry's workforce and customers report high and rising frustration with the way they are being treated. Can't the industry do better than this? Is it too much to expect the airline industry, or any other industry for that matter, to provide a fair return 
to investors, high quality and reliable service to their customers, and good jobs for their employees? Measured against these three expectations, US Airways is not alone. The U.S. airline industry is failing. In the first five years of the twenty-first century, U.S. airlines lost $\$ 30$ billion. Four of the largest airlines wiped out their equity investors by going into bankruptcy. In 2008 , there were only a few airlines in the world other than those owned by governments whose debt ratings put them above junk bond status. These few included Southwest, Qantas, and Lufthansa. In those five years, U.S. airlines also cut wages by more than $\$ 15$ billion and laid off one hundred thousand workers. Worker morale fell to all-time low levels. And customer complaints rose to record levels as companies cut the number of flights to fill planes and cut services and frills to save money. With all of this, as well as aging air traffic control technologies, labor problems with and shortages of air traffic controllers, and increased congestion and flight delays, industry commentators in the United States and overseas have expressed worries that a "perfect storm" may be coming. ${ }^{2}$

Is all of this the unavoidable consequence of the $9 / 11$ attacks on New York and Washington, D.C.? To some extent, yes. The sharp drop in air travel after $9 / 11$ made one-time losses and cutbacks inevitable. But it's more than that. This upheaval of losses, layoffs, wage cuts, and bankruptcies echoes previous periods in the early 1980 s and early 1990 s, highlighting the volatile nature of the industry. Booms are followed by contentious battles about wage increases, which are then followed by busts, accompanied by wrenching episodes of restructuring and concessions, which are followed by booms, as the cycle starts again. By 2006, as some U.S. airlines began to eke out modest profits, employees once again began raising their voices, asking for their fair share of whatever gains might be ahead-and the increasingly volatile up-and-down cycle of the industry seems destined to be repeated.

In each downturn, though, three important stakeholders suffer. Investors lose as company valuations drop and in some cases disappear. Employees, who have substantial firm-specific human capital, especially in an industry such as airlines in which compensation is often linked to firm-specific seniority, obviously suffer from layoffs and cuts to pay or other benefits. Customers suffer much-degraded service levels, as airlines cut back on amenities and delay needed investments in equipment and terminals, and as employees become more and more demoralized.

Yet the most recent upheaval reflects more than just another round of volatility. It also reflects a surge of new entrants that have spread price competition to an unprecedented degree. Around the world, the airline industry 
is becoming increasingly competitive as markets are deregulated and new entrants with low costs offer low fares. As a consequence, the industry is increasingly driven by cost-cutting pressures. This trend began in the United States after deregulation in the late 1970 s; new-entrant low-cost competitors have played an increasing role since the $1990 \mathrm{~s}$ and have continued to gain market share. They are growing even faster elsewhere in the world.

The annual number of miles flown by all passengers has grown by nearly 200 percent in the United States since deregulation, while the cost per mile has fallen by half, a growth rate and price performance that is not matched by any other relatively "mature" industry. In short, among the stakeholders in the airline industry, customers, especially customers in search of low prices, have been the winners. So if judged solely against the criterion of providing access for more consumers at low prices, airline deregulation would be judged a success. This is important. But while good for consumers' budgets, does increasing price competition necessarily mean negative consequences for investors and employees-and for the service quality that customers experience? Do low fares inevitably mean low-quality jobs? Is volatility a fact of life based on the industry's underlying characteristics? More ominously, will the degradation in human capital caused by lower and more volatile incomes, job security, and morale, along with the increased outsourcing of maintenance and other services, raise concerns about future safety? Are the risks of some type of meltdown in America's air transportation system increasing? Or, can we fashion a more sustainable, less volatile industry that better balances the objectives of customers, investors, employees, and the wider society? And does deregulation necessarily mean the abrogation of government's responsibility to oversee the industry, even as the industry shows clear signs of deterioration and an increasing risk of crisis?

These are reasonable, indeed vital, questions that are too seldom asked. Instead, too many business leaders assume that achieving low costs must mean low wages and no unions. As one veteran airline executive put it when discussing the state of the industry, "It's all about price." Too many union leaders assume that adversarial win-lose relations are the only model for labor-management relations. And too many policymakers accept as an article of faith that an unregulated market in which companies compete autonomously with strategies chosen by executives who are trying to maximize shareholder value is the best way to build an economy in a global marketplace--and the only way to compete. But at least one highly respected veteran airline industry executive, Robert Crandall, the former chief executive of American Airlines, believes the industry has suffered under the 
watch of government leaders who have been paralyzed by their blind faith in laissez-faire ideology:

There is no leadership it the federal level. We are in the grips of ideologues. We have had an administration that is convinced the market will solve the problem but the policies that make sense for the overall industry make no sense for the individual airlines and the policies that make sense for individual firms make no sense for the industry. ... It is a classic case of needing sensible government regulation. ${ }^{3}$

The narrow views of business, labor, and government leaders tend to ignore history, overlook important alternatives and variations, and suffer from a myopic, U.S.-centric view of the world. They forget that American policymakers found it necessary to introduce regulations to stabilize the airline industry in its early years so that the industry could expand in an orderly way to meet the nation's growing need for airline service. The same need for stability led policymakers to bring labor-management relations under the umbrejla of a transportation labor law that provided for mediation and other procedures to settle disputes without resort to strikes or other service disruptions and to allow wages to be taken out of competition.

These views also overlook the considerable variation in strategies and practices in the U.S. airline industry. Hidden beneath the bleak results at the industry level are examples of individual airlines, both low-cost entrants and much older or so-called legacy airlines, that have pursued alternative employment practices and achieved more positive results for all of their stakeholders-low prices, high-quality service, profits, relatively good jobs, and less volatility. Two U.S. firms that will feature prominently in our analysis, Southwest Airlines and Continental Airlines, consistently are found in the upper half of the service-quality rankings reported in table 1.1 and have been listed among the 100 best places to work by Fortune magazine. The question then becomes whether and how these examples can be emulated to achieve a better balance among stakeholders and reduce volatility across the industry.

Some countries recognize they still have a national interest in balancing the interests of the multiple stakeholders needed to support a sustainable airline industry-one marked by fewer episodic crises and one that doesn't lurch from one extreme to another-even as they move toward greater deregulation and negotiate "open skies" agreements. Around the world there are debates about different "varieties of capitalism," with most Anglo-Saxon countries exemplifying a shareholder-maximizing model of a market econ- 
Table 1.1. Service quality comparisons across U.S. Airlines

\begin{tabular}{lccc}
\hline & Consumer Complaints & On-Tine Arrivals & Mishandled Baggage \\
\hline Southwest & 0.3 & 80.4 & 6.0 \\
Alaska & 0.8 & 71.5 & 6.6 \\
JetBlue & 0.8 & 69.3 & 5.8 \\
Continentat & 1.1 & 74.7 & 5.7 \\
Northwest & 1.5 & 69.7 & 5.1 \\
Afnerican & 1.8 & 69.5 & 7.4 \\
Delta & 1.9 & 76.9 & 7.7 \\
United & 2.3 & 71.8 & 6.0 \\
US Airways & 3.4 & 68.0 & 8.8 \\
\hline
\end{tabular}

Note: Customer Complainls = complaints per 1,000 passengers, January-Seplernber, 2007. On Time Arrivals =Percent total on time arrivals, November 2006-0ctober 2007. Mishandled Baggage=Reports per 1,000 passengers, January-Septernber, 200 ?

Sources. Transportalion Depastment and Btoomberg Financial Markets. Reprinted irom Jeff Bailey, "Fliers Fed Up? The Employees Feel the Same, ${ }^{n}$ New York Times, December 22, 2007.

omy, while the Scandinavian and Germanic countries and Japan exemplify a more coordinated-market approach to governing their economies and to balancing the interests of different stakeholders. ${ }^{4}$

There is much to learn from these variations between companies as well as countries. But our research demonstrates that too many airlines, unions, and policymakers have been slow and reluctant learners. This book is an effort to open up the learning process. We do so by considering the trends as new entrants and legacy airlines around the world increasingly compete on costs. We discuss findings from case studies of airlines in the United States and other countries, analyzing the competitive strategies and the employment-relations strategies that airlines have adopted in response to economic pressures, and evaluate the outcomes for customers, employees, and other stakeholders. In particular, we will try to understand the lessons offered by airlines whose managers, unions, and employees have pursued and achieved more constructive relationships that reduce volatility, allow for quicker adaptation to changed conditions, and/or achieve low costs by providing good jobs that engage their workers. We conclude with recommendations for how the industry can better meet the needs of its multiple stakeholders.

\section{Why Are These Questions Important?}

One reason we should care about these issues goes to the heart of what citizens in an econony and society should expect from an industry. Most citizens 
are consumers and workers. ${ }^{5}$ As consumers we expect an industry to deliver good quality and safe products and services at affordable prices. And as workers we value good jobs that deliver on what some have called a social contract-hard work, loyalty, and good performance should be rewarded with dignity, good wages, and an opportunity to improve our economic security over time. Employment relationships should achieve a balance between efficiency and equity at work and should respect employees' right to have a voice in shaping the terms and conditions under which they work. ${ }^{6}$ At a more macro level, the expectation is that wages and standards of living should improve approximately in tandem with growth in productivity and profitability. This is the essence of the social contract that governed employment relations in the United States for decades following World War II. ${ }^{i}$ Wages and living standards did indeed rise in tandem with increases in productivity over that period. Unions and companies found ways to both enhance efficiency and to divide the fruits of their efforts in a more or less acceptable manner. This tandem movement began to erode in the 1970s and the erosion accelerated after 1980 . Between 1980 and 2005 , productivity grew by more than 70 percent while real compensation levels for nonmanagerial workers renained flat. At the same time executive compensation increased greatly, growing from about twenty times the average worker's wages in the 1950 s to between two hundred and four hundred times average wages in 2007. Few defend such an increase on either equity or efficiency grounds. ${ }^{8}$ The old social contract has broken down in the airline industry and more generally across other sectors of the American economy. Although changes in technology, markets, and the workforce make it impossible and perhaps even undesirable to return to the past, can a new social contract be fashioned, one better tailored to the contemporary economy and workforce? As employment-relations specialists, we see this as a critical challenge and responsibility facing the airline industry, labor, and government leaders.

There is a second concern that we bring to this analysis. Most airlines are highly unionized in the United States and in many other countries. Research has demonstrated that many of the traditions and practices of collective bargaining and labor relations that were developed during the twentieth century should be changed to meet the different needs of workers, employers, and the political economy of the twenty-first century. Yet labor relations in the U.S airline industry, and in other countries as well, have been painfully slow to change. Some of the pain that has been endured by the workforce and the industry in recent years reflects the failures of earlier efforts to change on a more gradual and consistent basis. Thus, the parties need to 
learn from past failures (as well as successes) so that they can avoid repeating past mistakes. The evidence from the expeniences of some parties shows there are better, more productive, and more satisfying ways to structure and govern employment relations in the airline industry. But it will take concerted and coordinated efforts from industry, labor, and government to lead the change process.

Beyond these employment-relations concerns, there is another dimension to "why this is important," specific to the airline industry, namely, the externalities and centrality of airlines to most countries and their economies. Airlines are a key part of the transportation infrastructure in most countries. They are important to national and international security. They help generate and support at least four times the number of jobs beyond the direct workers of the airlines and are fundamental to the economic growth and vitality of the communities they serve. Numerous jobs in other industries are facilitated by the direct jobs in airlines, including jobs in: airports, aerospace, tourism, hotels and hospitality, retailing, car hire, security, and many other services. One analysis estimates, for example, that, on a global scale, approximately five million direct airline jobs generate nearly twenty-five million jobs in other sectors. In the United States alone the approximately 450,000 airline jobs are complemented by another four million jobs that together contribute $\$ 410$ billion to the nation's gross domestic product. ${ }^{9}$ A study of one airport (Houston) estimated that airlines and related services accounted for 151,000 local jobs and $\$ 24$ billion in revenues for local businesses. ${ }^{10}$

Airlines are also embedded in a larger aviation infrastructure that is paid for and supported to varying degrees by local and national governments-air traffic control systems, airports, ground transport, and other facilities. In many countries airlines were or continue to be subsidized directly by national governments and in some cases they serve as iconic sources of national pride. Even in countries such as the United States, with multiple large carriers and an increasing number of new entrants where the possible demise of any single airline is likely to be offset by the growth or entry of others, the strength and sustained performance of the airline industry as a whole is of national concern. Thus, the strategies of individual airlines must be considered in the context of the sustainability of the industry nationally and globally.

We will also explore a question and worry we hear increasingly around the world: Is the Anerican model destined to be replicated elsewhere as other countries open their skies to increased international competition? $\mathrm{Or}$ 
will the cultural and institutional differences between countries moderate how airlines compete, engage their employees, and serve their customers? Alternatively, will American firms be able to compete with airlines that offer higher quality services and/or are more heavily subsidized or protected by their home countries?

The stakes are high and cover a wide range of concerns including the quality of employment relationships, the interests of national economies and societies, and the role of U.S. and international airlines in the global aviation industry.

\section{Our Analytical Framework}

Although the focus of our analysis is on the U.S. airline industry, we put the U.S. experience into a global context by drawing on the work of an international network of researchers who have used a similar analytical framework in studying airlines in other countries. We acknowledge in the preface many research colleagues who have conducted studies of airlines based in Australia, Canada, Ireland, Germany, Korea, Malaysia, Scandinavia, and the United Kingdom. ${ }^{11}$ By taking such a comparative perspective we avoid presenting the issues raised here as just an American problem, or one limited to American options or solutions. Those responsible for regulating the airline industry and employment relationships in other countries can also benefit from these international comparisons and from a more careful look at variations among companies in the United States. The "American model" is neither as uniform as many assume nor the only way to govern an industry or its employment relationships.

We approach the study of these issues by focusing on the variations in the national institutional confexts, firm-level business strategies, employment policies and practices, and the interconnections between these levels. None of these broad factors are the inevitable result of an "invisible hand" or deterministic force. The competitive environment, for example, is shaped by government policies and actions ranging from the degree and nature of competition allowed among airlines to the security and safety rules governing operations, from labor and employment regulations to the actions of airlines and unions. Thus, we take what bas been called a "strategic choice" perspective: government leaders, industry executives, and labor leaders have options for how to compete and how to structure their relationships and these choices have profound effects on the outcomes of interest to investors, employees, 
customers, and society. ${ }^{12}$ To be sure, the options chosen have to take account of competitive realities, technological changes, and other factors that may be outside their control. The task of analysts and decision makers is to understand how external constraints and strategic choices interact to shape the outcomes of concern to the different stakelholders.

\section{Competitive Positions and Strategy}

As we analyze the strategies of selected airlines in the United States and in some other countries, we will focus on their employment-relations strategies. At a high level, two basic competitive positions can be identified: legacy and new-entrant airlines, each of which operates with fairly distinct competitive strategies. At a more detailed level, although a range of decisions and dimensions might be relevant to defining competitive strategies, we will focus on how airlines achieve cost competitiveness.

Legacy and New-Entrant Airlines

Legacies (e.g., American, United, British Airways, Lufthansa, Qantas, and SAS) are airlines that were founded long before deregulation and were originally designed to compete in a regulated environment. Most of the new entrants to the industry (e.g., Southwest, AirTran, JetB]ue, Ryanair, easyJet, and Virgin Blue) were founded in anticipation of or after deregulation, and were designed to compete in a less regulated environment. For a number of reasons, new entrants tend to have significantly lower costs than legacieshence, they may also be referred to as low-cost airlines.

First, legacy and new-entrant airlines tend to have distinct product offerings. The legacy airlines have typically been "full service," while most of the new-entrant airlines began by featuring "no frills service." "Full service" airlines offer a range of amenities, such as flying out of primary airports (which are more convenient for many customers), and offering such "frills" as assigned seating, several classes of service, airport lounges, in-flight meals, drinks, entertainment, and baggage transfers between interconnecting flights. Such amenities are seen as important to attracting less price-sensitive business travelers. "No frills" airlines forego most of these amenities as a way to lower costs and thereby offer lower fares to the more price-sensitive leisure travelers that they have targeted, at least initially. 
Second, legacy airlines develop one or more hubs to maximize destination coverage and to defend their markets. Relative to the new entrants, this approach incurs the costs of higher airport fees as well as greater congestion and delays, which reduce aircraft utilization. In addition, this approach requires a more diverse fleet of aircraft to service routes of different density, which adds to the costs of maintenance and training.

The new entrants tend to rely less on hubs and are more likely to operate point-to-point route structures instead. They can therefore rely more easily on a single aircraft type, increasing aircraft utilization and lowering the costs of maintenance and training.

Third, due to their age, legacy airlines tend to have older employees and older aircraft than the new entrants, and the higher costs associated with both, such as higher wages due to seniority, higher pension costs, higher retiree health-care benefits, and less fuel-efficient aircraft. Some legacy airlines have also accumulated work rules that limit work flexibility and fleets that include many types of aircraft acquired in different periods. There is more variation in the current age of the newer entrants, however, particularly in the United States where deregulation occurred thirty years ago. Southwest Airlines, the oldest in this category, was founded in 1971, while JetBlue is one of the youngest, founded only in 2000. Outside the United States, Ryanair was founded in 1985 in Ireland, but it was not initially run as a low-cost airline; the other new entrants in the rest of the world are much younger.

\section{Strategies tor Cost Reduction}

Given that legacy and new-entrant airlines are increasingly competing on costs-because of increasing deregulation and the increase in the number of new entrant airlines-a second critical strategic dimension is how they choose to be cost competitive. One option is to focus on achieving low labor costs by minimizing wages and benefits, keeping staffing as lean as possible, and avoiding unionization or limiting union influence if or when employees organize. Another option is to focus instead on achieving low total costs by increasing employee and aircraft productivity as well as the productivity of other costly assets such as airport gates-for example, by speeding up the turnaround time of aircraft at the gate. We present Ryanair as the prototype new entrant of the former approach and Southwest as a prototype that has adopted the latter strategy. Although these are presented as two contrasting 
Strategic Position

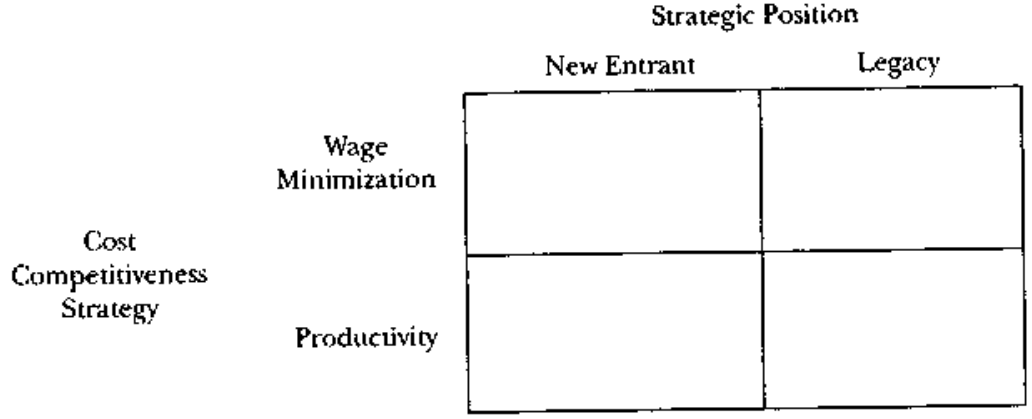

Figure 1.1. Competitive strategies.

or distinct options, in reality most airlines pursue some mixture of the two strategies and can be placed somewhere on a continuum between the two options.

Figure 1.1 lays out a simple two-by-two matrix that we will use to classify legacy and new-entrant airlines according to which of these two strategies dominate their efforts at cost reduction.

\section{Employment-Relations Strategy}

Alongside these differences in competitive strategies, we analyze differences in two aspects of employment-relations strategies. In their relationship with employees, airlines can focus either on controlling employee behavior or on engaging their commitment to the goals of the airline. In their relationship with unions, airlines can seek to avoid, accommodate, or partner with them. Both dimensions of employment-relations strategy are depicted in figure 1.2 .

\section{Control or Commitment}

Airlines and other enterprises have two primary options when it comes to managing their employees. Under the control approach, managers specify what needs to be done and instruct employees to comply with those directions..$^{13}$ The workplace is characterized by a fairly rigid hierarchy and narrowly defined jobs. Employees are expected to come to work and just do their job. By contrast, managers following the commitment approach seek to 
Relationship with Unions

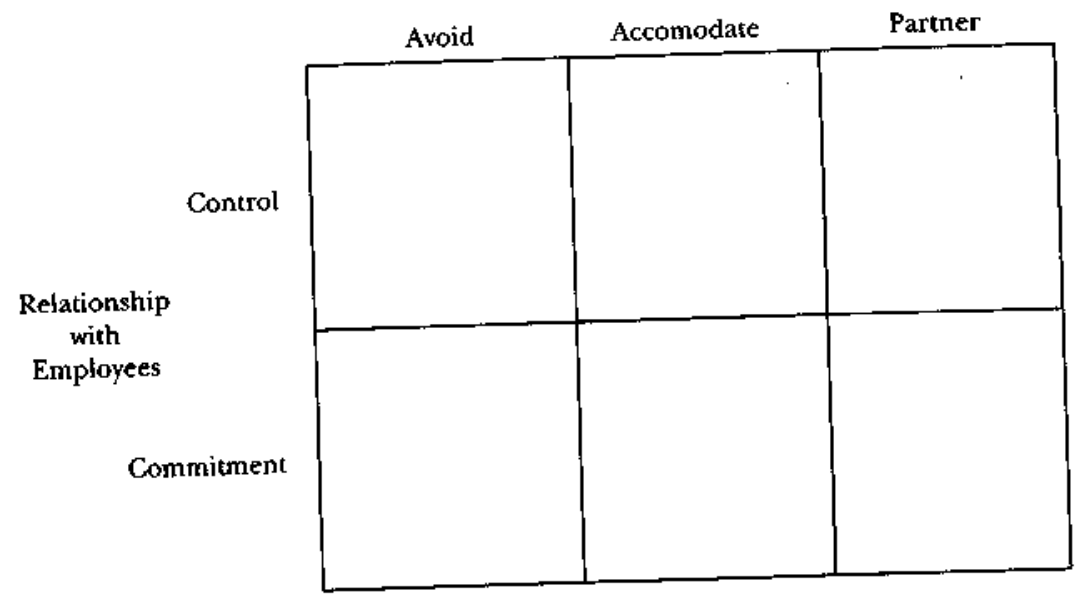

Figure 1.2. Employment-relations strategies.

Source: Richard E. Walton, Joel Cutcher-Gerslienfeld, and Robert B. McKersie, Strategic Negotiations (Boston: Harvard Business School Press, 1994).

generate a deeper, more organic relationship between employees and the organization. Their focus is on engaging employees to understand the interests of the enterprise and its customers and to act accordingly. Employees are encouraged to be committed to the enterprise and its decisions and in return the enterprise promises commitment to the long-term well-being of employees. The commitment approach is usually characterized by greater use of teamwork or cross-functional coordination, higher levels of employee discretion, and more flexible job boundaries.

\section{Avoid, Accommodate, or Partner wilh Unions}

There are also options when it comes to relations with unions. One option is to avoid having employees represented by unions, which can be pursued in two ways. ${ }^{14}$ The first is union suppression-voicing strong opposition and aggressively fighting the initial establishment of a union or undermining or challenging the existence of an already established union. The second strategy is union substitution-paying high wages and benefits and providing a work environment that reduces workers' incentives to, or perception of the need to, organize. ${ }^{15}$ 
Second, rather than avoiding unions, airlines can instead accommodate them, which means that they accept-however grudgingly — the basic legitimacy and existence of unions, negotiate with them at arm's length, and have a contractually based relationship with them.

A third option is to partner witl unions, seeking to establish a broader or deeper relationship than is contractually required. Companies and unions are engaged in more continuous communication. Unions are brought into the decision-making process earlier and on a wider range of issues in an attempt to find mutually acceptable solutions to the challenges that are faced by the airline, as opposed to interacting primarily via the negotiation and adjudication of the collective bargaining contract. Partnering can be either formal or informal. In formal or structural partnerships, unions are involved in the governance of the firm, typically through ownership stakes, representation on the board of directors, or formal consultation processes. In informal partnerships, unions are involved through consultation or problemsolving processes that are not built in to the governance structure of the airline.

\section{Stakeholder Outcomes}

One of our key questions is how do different competitive and employmentrelations strategies induce different outcomes on measures of importance to airlines' various stakeholders? What outcome measures are important? For airlines and investors, important outcomes include productivity, cost competitiveness (relative unit cost levels), and profitability. For customers, an important outcome, in addition to price, is service quality.

It is important to recognize three distinct dimensions of service quality. One dimension involves the level of amenities or "frills," as mentioned above (e.g., assigned seats, free meals, first class, and so forth). A second dimension is "reliability," particularly an airline's on-time and lost baggage performance. The third dimension is "friendliness": how an airline's staff--on the phone, on the ground, in the air-interacts with customers. These quality distinctions are achieved in different ways. Amenities can be imitated via additional investments and higher costs, whereas reliability and friendliness do not necessarily require higher costs but instead stem from superior operational coordination and workforce motivation. Airlines that rate highly on one dimension will not automatically rate highly on the other two. We keep these distinctions in mind in our analyses. 
For employees, important outcomes include income levels, employment security, morale, and job satisfaction. This is linked to the idea of human resource advantage and the burgeoning literature on people (employees) as a source of competitive advantage. ${ }^{16}$ Some potential sources of competitive advantage (e.g., new planes) can be fairly easily replicated via capital investment, whereas others, such as the reliability or "friendliness" of customer service, cannot be so easily replicated (e.g., will staff use their initiative or "run the extra mile" to help to solve problems that might not always be easily predictable or programmed). ${ }^{i \overline{ }}$

\section{What's to Come}

In the chapters that follow, we explore the competitive strategies and employment-relations strategies found in the United States (chapter 2) and in a range of other countries (chapter 3), before and after deregulation. In chapter 4 we analyze recent trends in quality, productivity, and costs, as well as employee outcomes. In chapter 5 we look more closely at selected new-entrant airlines and find a wide range of competitive and employmentrelations strategies being used in this segment of the industry. In chapter 6 , we examine several legacy airlines and identify the distinct strategies they have adopted to respond to competitive pressures from new-entrant airlines. These chapters each focus on selected U.S. airlines and those based in some other countries. In chapter 7 , we summarize the strategies of new-entrant and legacy airlines, and offer lessons about how airlines can and do change their strategies over time in their efforts to compete more effectively.

We offer recommendations, using our historical and comparative analyses to discuss whether a path forward can be identified that can provide a better balance in stakeholder outcomes. We end on a positive note, arguing that if the parties learn from their experiences and from each other, in the United States and other countries, there is a path that deals with the pressures building up in the airline industry, offering hope for a better balance between investor, employee, customer, and societal interests. Key questions are whether and from where the leadership will come to get the industry moving down this path or whether the main parties might not take such action before there is a "perfect storm." 


\section{CHAPTER 2}

\section{Developments in the U.S. Airline Industry}

Labor relations in the U.S. airline industry have often been a high-stakes enterprise. The national interest in airlines was recognized in the 1930 s just as the industry was getting off the ground. After lobbying by the Air Line Pilots Association (ALPA), in 1936 the federal government brought airlines under the same labor law, the Railway Labor Act (RLA), that governs railroads, the other large transportation sector deemed worthy of national labor regulation. Thus the basic structure of labor relations in U.S. airlines was born. This structure came to be known as "class and craft" to signify that each occupational group--pilots, flight attendants, mechanics, customer service agents, and so forth-would have its own union and that each airline would negotiate separate agreements with each group. Under this law workers have the right to strike, but only after the government has provided mediation and only after other efforts to reach agreement have failed. The bargaining process under the RLA is described here:

\section{Negotiating in the U.S. Airline Industry}

Labor agreements in the US. airline industry do not have fixed expiration dates. Instead, they have "amendable" dates. After the amendable date, the provisions of the existing contract remain in effect until the parties reach a new agreement or until they have exhausted the provisions of the Railway Labor Act. New contract terms cannot be 
imposed unilaterally and strikes or lockouts cannot be initiated until the parties have progressed through several steps that are regulated by the National Mediation Board (NMB).

If the parties cannot reach a contract agreement on their own through direct negotiations, either side may then apply for mediation services from the NMB. Once in mediation, negotiations continue until an agreement is reached or until the NMB declares an impasse. At that point, the NMB offers the option of entering into binding arbitration. If either party rejects the offer of arbitration, the NMB "releases" the parties. Once released, the parties then enter a thirty-day "cooling-off period," during which time the existing contract provisions remain in effect. At the end of the cooling-off period, it the parties still have not reached an agreement, the NMB chooses whether to let the parties engage in "self-help"-that is, a strike by workers or a lockout or unilateral imposition of new contract terms by management-or recommend that the president create a Presidential Emergency Board (PEB). The PEB, composed of three neutral experts, is allowed thirty days to deliberate and formulate a recommended settlement. After the PEB issues its recommendations, another thirty-day cooling-off period begins. Finally, at the end of the second cooling-off period, the parties are free to engage in self-help. As a final recourse, atter the expiration of the second cooling-off period, the president can reler the case to Congress. Congress has the authority to legislate a settlement if it cannot get the parties to resolve the dispute by other means.

At the same time, Congress sought stability by bringing the airline industry under the authority of the Civil Aeronautics Board (CAB), which regulated the entry of new airlines, the routes individual airlines could fly, and the prices on all routes. Regulation was motivated by the destructive price wars that had occurred between large airlines in the early 1930s. But regulation was also motivated by the belief that airlines served two critical national interests-to provide reliable, safe transportation and to provide help to the nation in times of war or other crises.

From the 1930s to the end of the regulatory period in 1978 the airline industry expanded steadily. Just before deregulation, fourteen large airlines, classified as "major airlines" by the Department of Transportation, dominated the U.S. market, with another twenty-three smaller airlines serving various regional markets. By 1978, passengers were flying approximately 275 million miles per year. Unions grew significantly from the 1930 s to 1978 . At the time of deregulation unions represented about 45 percent of the workforce and more than 60 percent of the nonmanagerial workforce. Labor relations in the airline industry were similar to labor relations in other large-scale industries at that time. Wages and working conditions were governed by 
collectively bargained labor contracts that became filled with comprehensive and complex work rules.' The relationship between airlines and their employees was generally at arm's length, heavily regulated by these contracts. Altogether, the airlines of that era fit into the control/accommodation employment-relations categories (see figure 1.2).

Though wages were set through firm-by-firm, craft-by-craft negotiations, cross-firm wage standardization was achieved through pattern bargaining. After one major union-airline pair reached an agreement, negotiators at other airlines felt pressure to match it. Because the Civil Aeronautics Board passed wage increases on to consumers by granting price increases, pattern bargaining worked both for unions and for airlines.

Negotiations were not always harmonious. In 1958 management sought to strengthen its hand in bargaining by forming a "Mutual Aid Pact" in which airlines that gained revenue from increased business because of a strike at another airline would share that revenue with the airline suffering the strike. Northwest Airlines took the prize for collecting the most from this Mutual Aid Pact (Eastern Airlines was second) because it had the worst strike record of all major airlines before the Mutual Aid Pact was abolished in 1978 under deregulation. Thus ended the first major effort at industry solidarity in response to union bargaining power.

How did the large airlines compete before deregulation? Since they could not control prices and had only limited flexibility in choosing routes and even less unilateral discretion in abandoning routes that proved to be unprofitable, they attempted to differentiate on the basis of service quality and economies of scale.

With a few exceptions, there was little effort to turn employment relations or human resources into sources of competitive advantage. Among the legacy airlines, Delta Airlines was the major exception. Delta's historic approach to employee and labor relations involved an implicit commitment to high wages, lifetime employment, and a "family" culture with the intention of substituting for union representation and inducing high levels of service from its employees. Delta followed a commitment/avoidance employment-relations strategy (figure 1.2). For a long time, this approach helped Delta maintain a reputation for delivering high-quality service. Delta's approach also discouraged all employees except its pilots and dispatchers from unionizing. In addition to Delta, two new-entrant firms attempted to turn employment relations into a source of strategic advantage-Pacific Southwest Airlines (PSA) and Southwest Airlines. PSA was founded in 1949 and Southwest began operations in 1971 , both as small intrastate operations in California and Texas, respectively. Both 